\title{
Bacillus foraminis sp. nov., isolated from a non-saline alkaline groundwater
}

\author{
Igor Tiago, ${ }^{1,2}$ Carlos Pires, ${ }^{1,2}$ Vítor Mendes, ${ }^{1,2}$ Paula V. Morais, ${ }^{3,4}$ \\ Milton S. da Costa ${ }^{2,3}$ and António Veríssimo ${ }^{1,2}$ \\ Departamento de Zoologia', Centro de Neurociências de Biologia Celular², Departamento de \\ Bioquímica ${ }^{3}$ and Instituto do Ambiente e Vida ${ }^{4}$, Universidade de Coimbra, 3004-517 Coimbra, \\ Portugal
}

Correspondence

António Veríssimo averiss@ci.uc.pt
Recently we investigated the bacterial diversity of a groundwater at Cabeço de Vide in southern Portugal. The ophiolite-like geological background of this aquifer and its chemical characteristics strongly suggest serpentinization. This groundwater, which has an outflow at a temperature of $20 \cdot 5{ }^{\circ} \mathrm{C}$, has a high level of alkalinity ( $\left.\mathrm{pH} 11 \cdot 4\right)$ associated with an extremely low ionic concentration, with $\mathrm{Ca}^{2+}$ and $\mathrm{OH}^{-}$as the major chemical constituents (Tiago et al., 2004).

The majority of the populations recovered during this survey comprised high-G + C-content Gram-positive bacteria (Tiago et al., 2004). However, several low-G+Ccontent Gram-positive bacteria were also isolated; one strain, designated $\mathrm{CV} 53^{\mathrm{T}}$, was of particular interest and was found to be phylogenetically related to the lineage containing the type strain of the species Bacillus jeotgali of the family Bacillaceae. In this study, we describe the morphological, physiological, chemotaxonomic and phylogenetic characteristics of strain $\mathrm{CV}_{53}{ }^{\mathrm{T}}$. On the basis of our results we

The GenBank/EMBL/DDBJ accession number for the 16S rRNA gene sequence of strain $\mathrm{CV}_{53}{ }^{\top}$ is $\mathrm{AJ} 717382$.

A comparison of the fatty acid compositions of strain $C V 53^{\top}$ and $B$. jeotgali $\mathrm{YKJ}-10^{\top}$ is available as supplementary material in IJSEM Online. propose that strain $\mathrm{CV} 53^{\mathrm{T}}$ represents a novel species of the genus Bacillus.

Strain $\mathrm{CV}_{53}{ }^{\mathrm{T}}$ was isolated from a non-saline alkaline groundwater environment by using alkaline buffered medium 2 (ABM2), adjusted to $\mathrm{pH} 8 \cdot 5$, at $37^{\circ} \mathrm{C}$, as described previously (Tiago et al., 2004). The isolate was routinely cultured under the same conditions and maintained at $-70{ }^{\circ} \mathrm{C}$ in the same medium supplemented with $15 \%$ glycerol. Unless otherwise stated, all morphological examinations and biochemical and tolerance tests were performed on this medium after 6 days incubation, as described previously (Tiago et al., 2005).

The temperature range for growth of strain $\mathrm{CV} 53^{\mathrm{T}}$ was examined at temperatures between 10 and $50{ }^{\circ} \mathrm{C}$ in ABM2 liquid medium buffered at $\mathrm{pH} 7 \cdot 0,8 \cdot 0$ and $9 \cdot 0$. The $\mathrm{pH}$ range for growth was determined at $40{ }^{\circ} \mathrm{C}$ in the same medium buffered at $\mathrm{pH}$ values between $6 \cdot 0$ to $10 \cdot 0$. Growth in the presence of $\mathrm{NaCl}$ concentrations up to $5.0 \%(\mathrm{w} / \mathrm{v})$ was examined in liquid medium at $\mathrm{pH} 7 \cdot 5$ and $40{ }^{\circ} \mathrm{C}$, as described previously (Tiago et al., 2005).

Three different agar-based media were used to test for sporulation. Medium A contained $\left(1^{-1}\right) 5 \cdot 0 \mathrm{~g}$ Bacto peptone

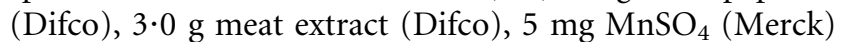
and $16 \mathrm{~g}$ agar (Difco) and medium B contained $\left(1^{-1}\right) 1 \cdot 0 \mathrm{~g}$ 
yeast extract (Difco), $1.0 \mathrm{~g}$ tryptone (Difco), $10 \cdot 0 \mathrm{~g}$ soluble starch (Merck) and $16 \mathrm{~g}$ agar (Difco). The third medium was ABM2 solid medium. All media were adjusted to $\mathrm{pH} 8 \cdot 0$. Plates were inoculated with $0 \cdot 3 \mathrm{ml}$ aliquots of an overnight liquid culture and then incubated at $40{ }^{\circ} \mathrm{C}$ for up to 15 days to determine the presence of spores. The heat resistance of the cells was determined using cultures in ABM2 medium and in ABM2 medium supplemented with $0.5 \%$ glucose. Aliquots $(5 \mathrm{ml})$ of the cultures were recovered at the exponential $(4 \mathrm{~h})$, late-exponential $(10 \mathrm{~h})$, stationary $(20 \mathrm{~h})$ and late-stationary $(48 \mathrm{~h}, 72 \mathrm{~h}$ and 10 days) phases and were heated at $80^{\circ} \mathrm{C}$ for $10 \mathrm{~min}$. Aliquots $(0.3 \mathrm{ml})$ of the heated cultures were inoculated onto ABM2 solid medium and incubated for $48 \mathrm{~h}$ at $40{ }^{\circ} \mathrm{C}$. In addition, the viability of the cells at each growth stage was checked by subculturing them on the same medium before heating.

The assimilation of single carbon sources was determined using API $50 \mathrm{CH}$ test strips (bioMérieux), using $0 \cdot 1 \mathrm{M}$ phosphate buffer $(\mathrm{pH} 7 \cdot 5)$ supplemented with $0.3 \%(\mathrm{w} / \mathrm{v})$ agar (Difco), $0 \cdot 05 \% \mathrm{NH}_{4} \mathrm{Cl}_{2}$ (Merck) and macronutrient and micronutrient solutions described previously (Tiago et al., 2005). Acid production from single carbon sources was determined using API $50 \mathrm{CH}$ test strips (bioMérieux), as recommended by the manufacturer. Results were recorded after incubation at $40{ }^{\circ} \mathrm{C}$ for $24 \mathrm{~h}, 48 \mathrm{~h}$ and 5 days. Anaerobic growth was assessed at $40{ }^{\circ} \mathrm{C}$ in an anaerobic chamber with a $\mathrm{H}_{2} / \mathrm{CO}_{2}$ atmosphere (bioMérieux).

Antibiotic susceptibility was determined after $72 \mathrm{~h}$ incubation on $\mathrm{ABM} 2(\mathrm{pH} 7 \cdot 5)$ at $40^{\circ} \mathrm{C}$, using discs (bioMérieux) containing amoxicillin $(25 \mu \mathrm{g})$, virginiamicin $(15 \mu \mathrm{g})$, ceftriaxon $(30 \mu \mathrm{g})$, cephalothin $(30 \mu \mathrm{g})$, ceftazidin $(30 \mu \mathrm{g})$, chloramphenicol $(30 \mu \mathrm{g})$, colistin $(50 \mu \mathrm{g})$, doxycycline
$(30 \mu \mathrm{g})$, gentamicin $(10 \mu \mathrm{g})$, kanamycin $(30 \mu \mathrm{g})$, lincomycin $(2 \mu \mathrm{g})$, nalidixic acid $(30 \mu \mathrm{g})$, ofloxacin $(5 \mu \mathrm{g})$, penicillin $\mathrm{G}(10 \mathrm{U} / \mathrm{IE})$, piperacilin $(100 \mu \mathrm{g})$, polymyxin B (300 $\mathrm{U} / \mathrm{IE})$, streptomycin $(10 \mu \mathrm{g})$ or tetracycline $(30 \mu \mathrm{g})$.

Strain $\mathrm{CV} 53^{\mathrm{T}}$ formed grey-pigmented colonies and comprised Gram-positive, rod-shaped cells $(1.0 \mu \mathrm{m}$ wide and $2 \cdot 4-3.9 \mu \mathrm{m}$ long). The isolate had an optimum growth temperature of about $40^{\circ} \mathrm{C}$ and did not grow at 10 or $50^{\circ} \mathrm{C}$. The optimum $\mathrm{pH}$ for growth of strain $\mathrm{CV} 53^{\mathrm{T}}$ was between $7 \cdot 0$ and $8 \cdot 5$, but no growth was observed at $\mathrm{pH} 6 \cdot 0$ or at $10 \cdot 0$. Optimal growth was observed in the absence of $\mathrm{NaCl}$, but poor growth did occur in ABM2 containing up to $3.0 \% \mathrm{NaCl}$. This organism was isolated from an environment with a $\mathrm{pH}$ of $11 \cdot 4$, but the optimum $\mathrm{pH}$ for growth under laboratory conditions was only around $8 \cdot 0$, and growth did not occur at $\mathrm{pH} 10 \cdot 0$. However, it is not uncommon for isolates from extreme alkaline environments to grow only at moderate $\mathrm{pH}$ values under laboratory conditions (Duckworth et al., 1998; Jones et al., 1998, 1994; Tiago et al., 2004). Furthermore, the optimum $\mathrm{pH}$ and temperature for growth and the halotolerance were only slightly different from those of $B$. jeotgali, the most closely related species (which has wider growth limits) (Table 1).

Despite all attempts to find spores, these were not observed; furthermore, the cells did not exhibit heat resistance when subjected to heating at $80^{\circ} \mathrm{C}$ for $10 \mathrm{~min}$, indicating that no spores were formed under the conditions tested. In addition, the cells became non-viable after 10 days incubation. To our knowledge, the only previously described Bacillus species incapable of spore formation is Bacillus thermoamylovorans (Combet-Blanc et al., 1995), but this micro-organism and strain $\mathrm{CV} 53^{\mathrm{T}}$ clearly belong to distinct phylogenetic lineages (Fig. 1).

Table 1. Phenotypic characteristics that differentiate strain $\mathrm{CV} 53^{\top}$ from $B$. jeotgali $\mathrm{YKJ}-10^{\top}$

Data for B. jeotgali YKJ-10 ${ }^{\mathrm{T}}$ were taken from Yoon et al. (2001).

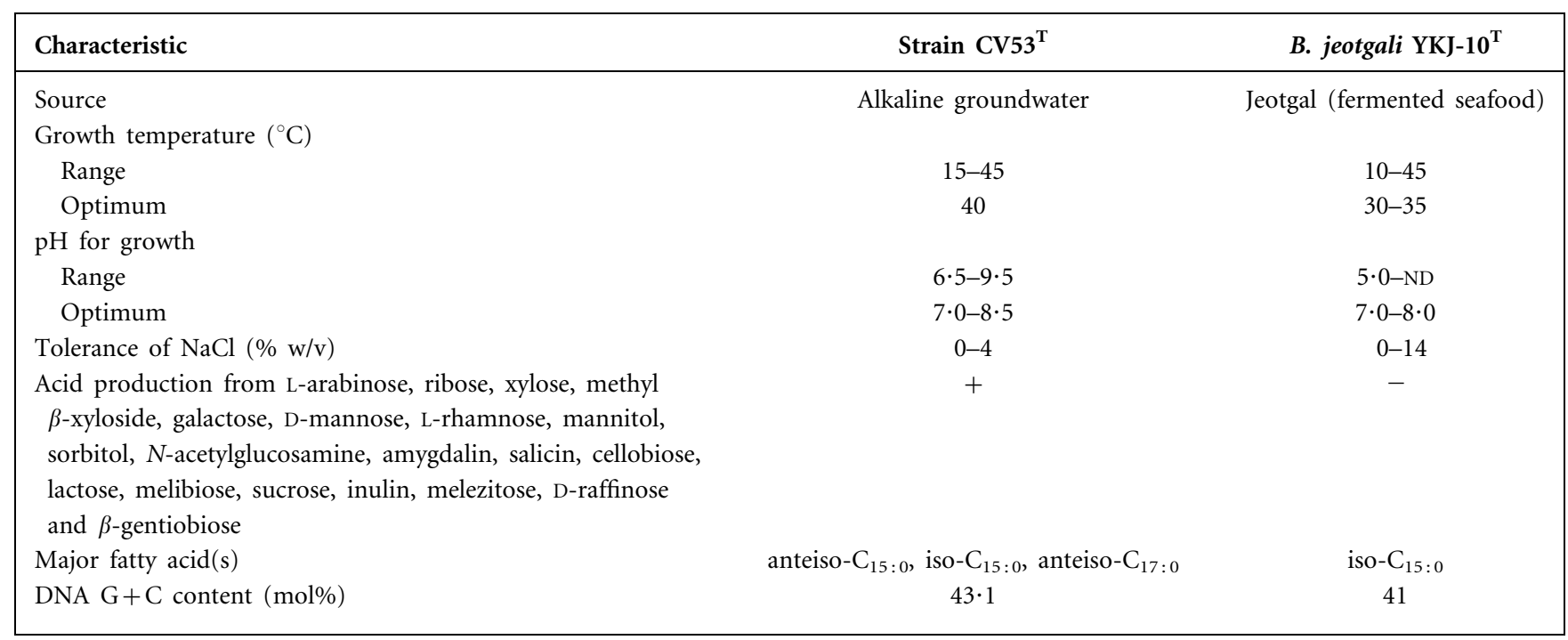




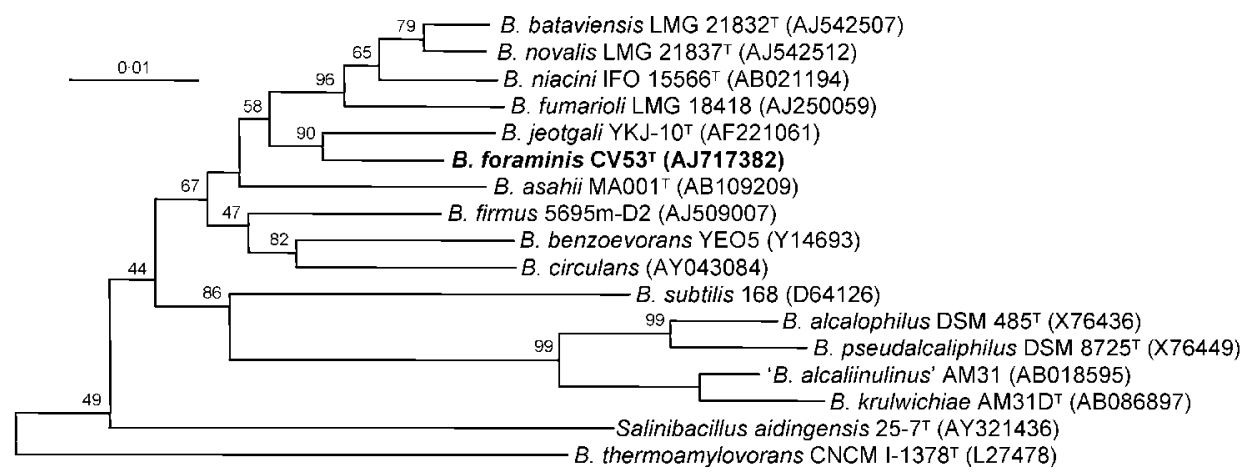

Fig. 1. Neighbour-joining phylogenetic dendrogram based on a comparison of the 16S rRNA gene sequences of strain $\mathrm{CV}_{5} 3^{\top}$ and some of its closest phylogenetic relatives. Numbers on the tree indicate bootstrap support (\%), derived from 1000 replications. Bar, 1 inferred nucleotide substitution per $100 \mathrm{nt}$.

Strain $\mathrm{CV} 3^{\mathrm{T}}$ utilized several sugars and proteinaceous substrates, and acid was produced from several single carbon sources, clearly differentiating strain $\mathrm{CV} 53^{\mathrm{T}}$ from the type strain of $B$. jeotgali (Table 1 ).

Cell-wall preparations and peptidoglycan for analysis were obtained as described previously (Schleifer \& Kandler, 1972; Schleifer, 1985). Lipoquinones were extracted and identified as described by Tindall (1989). Cultures used for fatty acid analysis were grown on $\mathrm{ABM} 2$ media, adjusted to $\mathrm{pH} 7 \cdot 5$, in sealed plastic bags submerged in a water bath at $40{ }^{\circ} \mathrm{C}$ for $24 \mathrm{~h}$; for comparison purposes, cultures grown on TSA medium at $28{ }^{\circ} \mathrm{C}$ for $24 \mathrm{~h}$ were also analysed. Fatty acid methyl esters were obtained from fresh wet biomass by saponification, methylation and extraction, and the fatty acids were identified and quantified by using the standard MIS Library Generation software (Microbial ID) as described by the manufacturer.

As in many other species of the genus Bacillus, the peptidoglycan of strain $\mathrm{CV} 53^{\mathrm{T}}$ belonged to the $\mathrm{A} 1 \gamma$ type, which contains meso-diaminopimelic acid as the diamino acid. The major respiratory quinone detected was MK-7. The fatty acid composition of the novel organism was made up mainly of anteiso- $\mathrm{C}_{15: 0}(29 \cdot 7 \%)$, iso- $\mathrm{C}_{15: 0}(29 \cdot 7 \%)$ and anteiso- $\mathrm{C}_{17: 0}(10 \cdot 6 \%)$, a profile that clearly differentiates strain $\mathrm{CV} 53^{\mathrm{T}}$ from $B$. jeotgali (see Supplementary Table S1 available in IJSEM Online).

DNA for the determination of the $\mathrm{G}+\mathrm{C}$ content was obtained as described by Nielsen et al. (1995) and HPLC was performed as described by Mesbah et al. (1989). The 16S rRNA gene was sequenced as described by Tiago et al. (2004) and phylogenetic analysis was performed using the ARB software package (Ludwig et al., 2004). Evolutionary distances were calculated using the Jukes-Cantor method (Jukes \& Cantor, 1969), phylogenetic dendrograms were constructed using the neighbour-joining method (Saitou \& Nei, 1987) and tree topologies were evaluated by performing bootstrap analysis (Felsenstein, 1985) of 1000 resamplings of the datasets.
The DNA G $+\mathrm{C}$ content determined for strain $\mathrm{CV} 53^{\mathrm{T}}$ was $43 \cdot 1 \mathrm{~mol} \%$. Comparative analyses of 1483 nucleotide positions of the $16 \mathrm{~S}$ rRNA gene sequence of strain $\mathrm{CV} 53^{\mathrm{T}}$ with sequences of representatives of the main lines of descent within the domain Bacteria indicated that the strain was a member of the family Bacillaceae. The novel isolate and the type strain of $B$. jeotgali formed a coherent cluster supported by bootstrap analysis at a confidence level of $90 \%$, showing the phylogenetic relatedness of the two strains (Fig. 1). The pairwise similarity of the 16S rRNA gene sequences of the two strains was $97 \cdot 7 \%$. Although CV53 $3^{\mathrm{T}}$ was isolated from an alkaline environment, it does not have a close phylogenetic relationship with micro-organisms on the phylogenetic branch that includes some of the most alkaliphilic Bacillus species, namely Bacillus alcalophilus, Bacillus pseudoalcalophilus and Bacillus krulwichiae (Fig. 1).

The phylogenetic relationships of strain $\mathrm{CV} 53^{\mathrm{T}}$, together with its distinctive phenotypic and chemotaxonomic characteristics, justify the proposal that it represents a novel species of the genus Bacillus. Moreover, the novel isolate can be differentiated from the most closely related species, B. jeotgali, on the basis of several characteristics (Table 1). Consequently, we propose that strain $\mathrm{CV} 53^{\mathrm{T}}$ represents a novel species of the genus Bacillus, for which we propose the name Bacillus foraminis sp. nov.

\section{Description of Bacillus foraminis sp. nov.}

Bacillus foraminis (fo.ra'mi.nis. L. n. foramen -inis a hole; L. gen. n. foraminis from a hole).

Forms rod-shaped cells, $1 \mu \mathrm{m}$ wide and $2 \cdot 4-3 \cdot 9 \mu \mathrm{m}$ long. Gram stain is positive. Spores are not observed under a range of conditions; cells are killed by heating at $80^{\circ} \mathrm{C}$ for $8 \mathrm{~min}$. Aerobic and heterotrophic. Nitrate is reduced to nitrite. Colonies are small, smooth, convex and grey. Oxidase- and catalase-positive. The optimum temperature for growth is about $40^{\circ} \mathrm{C}$; no growth occurs at 10 or $50^{\circ} \mathrm{C}$. The optimum $\mathrm{pH}$ is between $7 \cdot 0$ and $8 \cdot 5$; no growth occurs at $\mathrm{pH} 6 \cdot 0$ or $10 \cdot 0$. Does not require $\mathrm{NaCl}$ for growth, but 
tolerates up to $3 \cdot 0 \% \mathrm{NaCl}$. The diamino acid of the peptidoglycan is meso-diaminopimelic acid (A $1 \gamma$ type). The major respiratory quinone is $\mathrm{MK}-7$. The predominant fatty acids are anteiso- $\mathrm{C}_{15: 0}(29 \cdot 7 \%)$, iso- $\mathrm{C}_{15: 0}(29 \cdot 7 \%)$ and anteiso- $\mathrm{C}_{17: 0}(10 \cdot 6 \%)$. Does not hydrolyse casein or elastin. Hydrolyses aesculin, hippurate, starch, gelatin and arbutin. Urease, $\beta$-galactosidase and DNase are detected. Xylanase and arginine dihydrolase are not detected. Sensitive to amoxicillin, cephalothin, chloramphenicol, doxycycline, ofloxacin, penicillin G, streptomycin and tetracycline. Assimilates arabinose, xylose, methyl $\beta$-xyloside, galactose, glucose, fructose, mannose, rhamnose, inositol, mannitol, sorbitol, $\mathrm{N}$-acetylglucosamine, amygdalin, salicin, cellobiose, maltose, lactose, melibiose, sucrose, trehalose, melezitose, raffinose, $\beta$-gentiobiose, turanose, gluconate and 2 -ketogluconate. Acid is produced from glycerol, arabinose, ribose, xylose, methyl $\beta$-xyloside, galactose, glucose, fructose, mannose, rhamnose, inositol, mannitol, sorbitol, $N$ acetylglucosamine, amygdalin, arbutin, salicin, cellobiose, maltose, lactose, melibiose, sucrose, trehalose, inulin, melezitose, raffinose, starch, glycogen, $\beta$-gentiobiose, turanose, gluconate and 2-ketogluconate. The DNA G $+C$ content of the type strain is $43 \cdot 1 \mathrm{~mol} \%$.

The type strain, $\mathrm{CV}^{2} 3^{\mathrm{T}}\left(=\mathrm{LMG} 23174^{\mathrm{T}}=\mathrm{CIP} 108889^{\mathrm{T}}\right.$ ), was isolated from groundwater taken from the borehole at Cabeço de Vide in southern Portugal.

\section{Acknowledgements}

This research was funded, in part, by FCT/FEDER project POCTI/BSE/ $42732 / 2001$. We are indebted to Dr J. Euzéby (École National Vétérinaire, Toulouse, France) for the etymology of the name of the novel organism. We thank Dr Peter Schumann (Deutsche Sammlung von Mikroorganismen und Zellkulturen, Braunschweig, Germany) for determining the peptidoglycan structure and Dr Fernanda Nobre (Universidade de Coimbra, Portugal) for helping with the fatty acid methyl ester analysis, and we also thank the Junta de Freguesia de Cabeço de Vide and Mr Manuel Fontainhas for permission to collect the water samples.

\section{References}

Combet-Blanc, Y., Ollivier, B., Streicher, C., Patel, B. K., Dwivedi, P. P., Pot, B., Prensier, G. \& Garcia, J. L. (1995). Bacillus thermoamylovorans sp. nov., a moderately thermophilic and amylolytic bacterium. Int J Syst Bacteriol 45, 9-16.

Duckworth, A. W., Grant, S., Grant, W. D., Jones, B. E. \& Meijer, D. (1998). Dietzia natronolimnaios sp. nov., a new member of the genus Dietzia isolated from an East African soda lake. Extremophiles 2, 359-366.

Felsenstein, J. (1985). Confidence limits on phylogenies: an approach using the bootstrap. Evolution 39, 783-791.

Jones, E. B., Grant, W. D., Collins, N. C. \& Mwatha, W. E. (1994). Alkaliphiles: diversity and identification. In Bacterial Diversity and Systematics, pp. 195-230. Edited by F. G. Priest. New York: Plenum Press.

Jones, E. B., Grant, W. D., Duckworth, A. W. \& Owenson, G. G. (1998). Microbial diversity of soda lakes. Extremophiles 2, 191-200.

Jukes, T. H. \& Cantor, C. R. (1969). Evolution of protein molecules. In Mammalian Protein Metabolism, pp. 21-132. Edited by H. N. Munro. New York: Academic Press.

Ludwig, W., Strunk, O., Westram, R. \& 29 other authors (2004). ARB: a software environment for sequence data. Nucleic Acids Res 32, 1363-1371.

Mesbah, M., Premachandran, U. \& Whitman, W. B. (1989). Precise measurement of the $\mathrm{G}+\mathrm{C}$ content of deoxyribonucleic acid by highperformance liquid chromatography. Int J Syst Bacteriol 39, 159-167.

Nielsen, P., Fritze, D. \& Priest, F. G. (1995). Phenetic diversity of alkaliphilic Bacillus strains: proposal for nine new species. Microbiology 141, 1745-1761.

Saitou, N. \& Nei, M. (1987). The neighbor-joining method: a new method for reconstructing phylogenetic trees. Mol Biol Evol 4, 406-425.

Schleifer, K. H. (1985). Analysis of the chemical composition and primary structure of murein. Methods Microbiol 18, 123-156.

Schleifer, K. H. \& Kandler, O. (1972). Peptidoglycan types of bacterial cell walls and their taxonomic implications. Bacteriol Rev 36, 407-477.

Tiago, I., Chung, A. \& Veríssimo, A. (2004). Bacterial diversity in a nonsaline alkaline environment: heterotrophic aerobic populations. Appl Environ Microbiol 70, 7378-7387.

Tiago, I., Pires, C., Mendes, V., Morais, P. V., da Costa, M. \& Verissimo, A. (2005). Microcella putealis gen. nov., sp. nov., a grampositive alkaliphilic bacterium isolated from a nonsaline alkaline groundwater. Syst Appl Microbiol 28, 479-487.

Tindall, B. J. (1989). Fully saturated menaquinones in the archaebacterium Pyrobaculum islandicum. FEMS Microbiol Lett 60, 251-254.

Yoon, J. H., Kang, S. S., Lee, K. C., Kho, Y. H., Choi, S. H., Kang, K. H. \& Park, Y. H. (2001). Bacillus jeotgali sp. nov., isolated from jeotgal, Korean traditional fermented seafood. Int J Syst Evol Microbiol 51, 1087-1092. 